Société d'histoire de la révolution de 1848 et des

révolutions du XIXe siècle

$19 \mid 1999$

Aspects de la production culturelle au XIXe siècle

\title{
" Bibliothèques " et collections au XIXe siècle : essai de périodisation comparée
}

Isabelle Olivero

\section{OpenEdition \\ Journals}

Édition électronique

URL : http://journals.openedition.org/rh19/155

DOI : $10.4000 /$ rh 19.155

ISSN : $1777-5329$

Éditeur

La Société de 1848

Édition imprimée

Date de publication : 1 décembre 1999

Pagination : 65-76

ISSN : 1265-1354

Référence électronique

Isabelle Olivero, " "Bibliothèques " et collections au XIXe siècle : essai de périodisation comparée », Revue d'histoire du XIXe siècle [En ligne], 19 | 1999, mis en ligne le 26 août 2008, consulté le 20 avril 2019. URL : http://journals.openedition.org/rh19/155 ; DOI : 10.4000/rh19.155

Ce document a été généré automatiquement le 20 avril 2019

Tous droits réservés 


\title{
" Bibliothèques " et collections au XIXe siècle : essai de périodisation comparée
}

\author{
Isabelle Olivero
}

\section{RÉSUMÉS}

S'intéresser à la formule éditoriale de la collection, telle qu'elle naît au XIXe siècle, autorise plusieurs regards croisés : sur les rythmes d'évolution de cette formule, sur les différents types adoptés - "Bibliothèque " universelle, collection de propagande, etc., et sur les productions similaires ou proches existant au même moment dans les pays européens voisins. De cette manière peuvent être posés les jalons d'une histoire des collections qui nous conduit de la Bibliothèque bleue aux plus récentes collections de l'édition contemporaine.

The study of the editorial strategies of paperback collections, first launched in France in the nineteenth century, opens several perspectives on the changing rythms of this new formula. Such a study also permits an understanding of the different types of books developed such as the "Bibliothèque" and the collections of political and religious propaganda and of the paperbacks in neighboring European countries. In general, these perspectives lay the grounds for a history of paperback collections that link the Bibliothèque bleue to the most recent releases of contemporary publishers.

\section{INDEX}

Mots-clés : Edition, Histoire culturelle 